\title{
Coronavirus Disease-19: Public Health Nurses' Knowledge, Attitude, Practices, and Perceived Barriers in Indonesia
}

\author{
Junaiti Sahar ${ }^{1}$, Stefanus Mendes Kiik ${ }^{2 \star}$, Wiwin Wiarsih ${ }^{1}$, Utami Rachmawati ${ }^{1}$ \\ ${ }^{1}$ Public Health Nursing Department, Faculty of Nursing, Universitas Indonesia, Depok, Indonesia; ${ }^{2}$ Public Health Nursing \\ Department, School of Nursing, STIKES Maranatha Kupang, Kupang, Indonesia
}

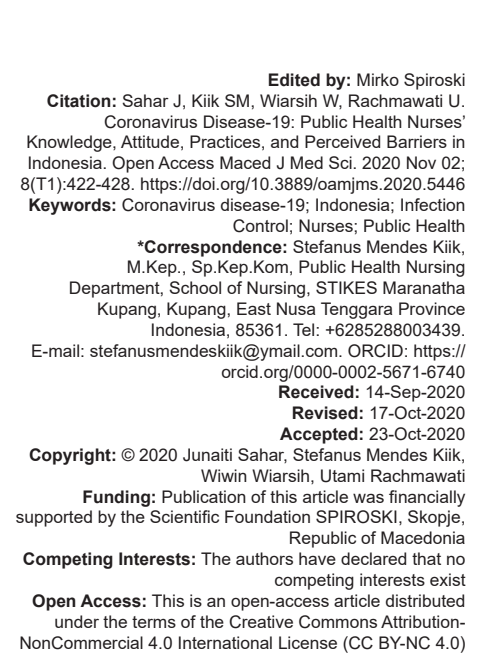

\section{Abstract}

BACKGROUND: The coronavirus disease (COVID)-19 outbreaks and its rapid rise in prevalence has been a major concern internationally. We conducted a short survey to understand the knowledge, attitude, and practices regarding COVID-19 and estimated barriers to disease transmission perceived by public health nurses (PHN) in Indonesia.

AIM: The study aimed to identify the association of sociodemographic characteristic with knowledge, attitude, and practices regarding COVID-19 among PHNs in Indonesia and highlight barriers to the control of infection perceived by PHNs.

METHODS: A national, online, and cross-sectional survey was conducted from May 28 to June 9, 2020, with a tota of 368 participants. A questionnaire was used to assess knowledge, attitude, and practice. An independent t-test was used to compare attitude differences of PHNs in gender and place of work. One-way analysis of variance was used to compare differences in attitude of PHNs by age, work experience, educational level, and source of information. The Pearson's correlation test was used to measure the correlation between knowledge, attitude, and practices.

RESULTS: The majority of participants had good knowledge of COVID-19 (77.4\%), had mean scores of attitude toward COVID-19 of $33.0 \pm 2.7$, and had good practices regarding COVID-19 (84.2\%). Factors associated with knowledge were sources of information $(p=0.013)$. Factors associated with attitude were gender $(p=0.003)$, work experience $(p=0.010)$, and sources of information $(p=0.035)$. Factors associated with practices were gender $(p=0.011)$ and sources of information $(p=0.029)$. There were significant, positive linear correlations between knowledge and attitude $(r=0.435, p=0.000)$, knowledge and practices $(r=0.314, p=0.000)$, and attitude and practices $(r=0.362, p=0.000)$. Most participants strongly agreed that limitations on infection control materials $(50.8 \%)$ and patients hiding their travel history, resulting in screening inaccuracies $(59.8 \%)$, were barriers.

CONCLUSIONS: A significant association between sources of information and knowledge, attitude, and practices, with the addition of other related factors. There were also significant positive linear correlations between knowledge, attitude, and practices. Nevertheless, the majority of the PHN perceived that limitations on infection control materials and patients hiding their travel history, resulting in screening inaccuracy, were major barriers.

\section{Introduction}

Since the first reported case in Wuhan, China, in December 2019, the novel coronavirus of 2019 coronavirus disease (COVID-19) has spread quickly around the world [1]. COVID-19 has infected 216 countries to date. As of August 7, 2020, there had been 18,854,287 confirmed cases of COVID-19, including 708,639 deaths [2]. In Indonesia, as of August 7, 2020, there had been 121,226 confirmed COVID-19 cases and 5593 deaths related to the disease [3], including 49 Indonesian nurses [4].

Nurses, including public health nurses (PHNs), are on the front line of this crisis [5]. PHNs who work in public health centers have a vital role in the epidemic chain for controlling COVID-19. PHNs provide care for COVID-19 patients, families, and the community [6]. They provide safe, effective, and nondiscriminatory care to the communities in which they serve [5]. They must have contact with patients, are exposed to pathogens and are at high risk of infection [7]. PHNs who care for patients in their homes are among those at the highest risk in pandemics [8]. Nurses play additional roles in screening potential cases, recognizing patients' need for isolation or quarantine, and monitoring cases [9].

In public health centers, PHNs are responsible for care of asymptomatic patients and exposure to infected individuals. Lack of personal protective equipment and poor infection controls are risk factors for COVID-19 [10], [11]. Disease knowledge may affect attitude and practices [12]. Poor knowledge may lead to delayed diagnosis, disease transmission, and lack of infection control practices [13].

As healthcare workers (HCWs) in primary health centers, PHNs play an important role for preventing and controlling the spreading of COVID19. In the health care system in Indonesia, public health centers, as primary health care, treat and care for patients before transferring them to secondary or tertiary health care. Thus, it is important for PHNs to have adequate knowledge, attitude, and practices in considering and controlling infections. 
The study aimed to identify the association of sociodemographic characteristic with knowledge, attitude, and practices regarding COVID-19 among $\mathrm{PHNs}$ in Indonesia and highlight barriers to the control of infection perceived by PHNs.

\section{Materials and Methods}

\section{Design and subjects}

This was a national, online, cross-sectional survey. It was conducted from May 28 to June 9, 2020 , during the lockdown period in Indonesia. The investigators collected the data by an online method because of the current lockdown situation.

The sample size, calculated using a sample size calculator [14], was 368, assuming 95\% confidence level, a $Z$ of 1.96 , and a margin of error of $5 \%$. The population used in this study comprised Indonesian PHNs working in public health centers (Puskesmas) in Indonesia. Participants from all 34 provinces in Indonesia were eligible to participate.

\section{Data collection}

A questionnaire was designed using Google Forms. The questionnaire's link was shared to Indonesian PHNs' WhatsApp group and, alternatively, personally to PHNs in the contact lists of the investigators. The questionnaire included an introduction to the study containing the title, aims, procedures, voluntary participation, declarations of anonymity and confidentiality, and notes for filling in the questionnaire. Reliability was calculated using Cronbach's alpha was 0.813 . The data from the pilot study were not used in the final analysis.

\section{Measurements}

The questionnaire was adapted from Saqlain et al. [15]. Permission to use and modify the questionnaire was obtained, and required modifications were done. The questionnaire consisted of three parts: Sociodemographic characteristics; knowledge, attitude, and practices; and perceived barriers to disease transmission. The sociodemographic characteristics included age, gender, work experience, living area, educational level, place of work, and sources of information. Responses are presented as frequencies and percentages. The knowledge variable consisted of 12 items and each question was answered "yes," "no," or "don't know." The scoring of the knowledge questions was determined by giving 1 point for each correct answer and 0 for an incorrect answer or unknown answer. The total knowledge score ranged from 0 to 12 , with a higher score denoting a better knowledge of COVID-19. The attitude variable included seven items, and responses were recorded on a five-point Likert scale (1, strongly agree; 2 , agree; 3, undecided; 4, disagree; 5 , strongly disagree). The total attitude score ranged from 7 to 35, with a higher score denoting a positive attitude toward COVID19. The practices variable contained seven items and each item was answered "yes" (1 point), "no" (0 points) or "sometimes" (0 points). The total practices score ranged from 0 to 7 , with a higher score denoting better practices regarding COVID-19. Seven items assessed the perception of PHNs regarding barriers to controlling infection. Responses were recorded on a five-point Likert scale (strongly agree, agree, undecided, disagree, strongly disagree). Responses are presented as frequencies and percentages.

\section{Ethics approval}

This study was approved by the Ethics Committee of National Health Research and Development, Ministry of Health, Republic of Indonesia, with approval number LB.02.03/1/0033/2020. The participants had to answer a yes-no question to confirm their willingness to participate voluntarily. After a yes confirmation, the participant was directed to complete a self-report instrument.

\section{Data analysis}

The data were analyzed with SPSS software version 21. A Chi-square test was used to understand how sociodemographic characteristics related to knowledge and practices of PHNs. An independent t-test was used to compare attitude differences of $\mathrm{PHN}$ in gender and place of work. One-way analysis of variance was used to compare differences in attitude of PHNs by age, work experience, educational level, and source of information. The Pearson's correlation test was used to measure the correlation between knowledge, attitude, and practices.

\section{Results}

A total of 368 PHNs participated in this study. Table 1 shows the demographic characteristics of the participants.

The largest percentage of participants were women $(70.1 \%)$ and $31-39$ years old $(43.2 \%)$, had more than 10 years of work experience (44.8\%), lived in central Indonesia (49.2\%), held a diploma (61.4\%), had a rural workplace $(54.9 \%)$, and got information about COVID-19 from social media (40.2\%). The 
majority had good knowledge of COVID-19 (77.4\%), with mean scores of attitude toward COVID-19 of $33.0 \pm 2.7$, and good practices regarding COVID-19 (84.2\%).

Table 1: Sociodemographic characteristics of participants ( $\mathrm{n}=368)$

\begin{tabular}{|c|c|}
\hline Characteristics & $\mathrm{n}(\%)$ \\
\hline \multicolumn{2}{|l|}{ Age } \\
\hline$\leq 30$ years & $100(27.2)$ \\
\hline $31-39$ years & $159(43.2)$ \\
\hline $40-49$ years & $85(23.1)$ \\
\hline$\geq 50$ years & $24(6.5)$ \\
\hline \multicolumn{2}{|l|}{ Gender } \\
\hline Female & $258(70.1)$ \\
\hline Male & $110(29.9)$ \\
\hline \multicolumn{2}{|l|}{ Work experience } \\
\hline$\leq 5$ years & $94(25.5)$ \\
\hline $6-10$ years & $109(29.6)$ \\
\hline$>10$ years & $165(44.8)$ \\
\hline \multicolumn{2}{|l|}{ Living area } \\
\hline Eastern Indonesia & $45(12.2)$ \\
\hline Central Indonesia & $181(49.2)$ \\
\hline Western Indonesia & $142(38.6)$ \\
\hline \multicolumn{2}{|l|}{ Educational level } \\
\hline Diploma & $226(61.4)$ \\
\hline Bachelor's degree & $126(34.2)$ \\
\hline Master's degree & $16(4.3)$ \\
\hline \multicolumn{2}{|l|}{ Place of work } \\
\hline Rural & $202(54.9)$ \\
\hline Urban & $166(45.1)$ \\
\hline \multicolumn{2}{|l|}{ Source of information } \\
\hline Social media & $148(40.2)$ \\
\hline Television and radio & $37(10.1)$ \\
\hline Newspapers, magazines, posters, and pamphlets & $7(1.9)$ \\
\hline Nurses and other healthcare workers & $57(15.5)$ \\
\hline Seminars and Workshops & $17(4.6)$ \\
\hline WHO and ministry of health websites & $102(27.7)$ \\
\hline \multicolumn{2}{|l|}{ Knowledge } \\
\hline Poor & $83(22.6)$ \\
\hline Good & $285(77.4)$ \\
\hline Attitude: Mean \pm SD & $33.0 \pm 2.7$ \\
\hline \multicolumn{2}{|l|}{ Practices } \\
\hline Poor & $58(15.8)$ \\
\hline Good & $310(84.2)$ \\
\hline
\end{tabular}

The results of the study demonstrate that age, gender, work experience, living area, educational level, and place of work were not significantly associated with knowledge. The factor associated with knowledge was the source of information ( $p=0.013$; Table 2).
The findings demonstrate that age, work experience, living area, educational level, and place of work were not significantly associated with practices. Factors associated with practices were gender $(p=0.011)$ and source of information ( $p=0.029$; Table 2).

The findings demonstrate that there were no significant differences of attitude in age, living area, educational level, and place of work. However, there were significant differences in gender $(p=0.003)$, work experience $(p=0.010)$, and source of information ( $p=0.035$; Table 3$)$.

There were significant, positive linear correlations between knowledge and attitude $(r=0.435$, $\mathrm{p}=0.000)$, knowledge and practices $(r=0.314$, $p=0.000)$, and attitude and practices $(r=0.362$, $\mathrm{p}=0.000$; Table 4).

The largest percentage of participants agreed that a lack of knowledge about the mode of transmission of COVID-19 (39.9\%), a lack of policies and procedures regarding infection control (37.8\%), insufficient training on infection control measurement (39.4\%), less commitment of PHNs to the policies and procedures $(33.4 \%)$, no technical or management instructions for handling COVID-19 patients (26.4\%), and no psychological counseling (38.6\%) were barriers. Most participants strongly agreed that limitations on infection control materials (50.8\%) and patients hiding their travel history, resulting in screening inaccuracies $(59.8 \%)$, were barriers. The largest percentage of participants disagreed that not wearing a mask while examining or being in contact with patients $(25.5 \%)$ and not handwashing after examining or being in contact with patients $(32.1 \%)$ were barriers (Figure 1).

Table 2: Comparison of sociodemographic characteristics between public health nurses with different knowledge and practices $(\mathrm{n}=368)$

\begin{tabular}{|c|c|c|c|c|c|c|}
\hline \multirow[t]{2}{*}{ Variables } & \multicolumn{2}{|c|}{ Knowledge } & \multirow[t]{2}{*}{$p$-value } & \multicolumn{2}{|l|}{ Practices } & \multirow[t]{2}{*}{$p$-value } \\
\hline & Poor & Good & & Poor & Good & \\
\hline \multicolumn{7}{|l|}{ Age } \\
\hline$\leq 30$ years & $22(6.0)$ & $78(21.2)$ & \multirow[t]{4}{*}{0.871} & $20(5.4)$ & $80(21.7)$ & \multirow[t]{4}{*}{0.221} \\
\hline $31-39$ years & $36(9.8)$ & $123(33.4)$ & & $25(6.8)$ & $134(36.4)$ & \\
\hline $40-49$ years & $18(4.9)$ & $67(18.2)$ & & $8(2.2)$ & $77(20.9)$ & \\
\hline$\geq 50$ years & $7(1.9)$ & $17(4.6)$ & & $5(1.4)$ & $19(5.2)$ & \\
\hline \multicolumn{7}{|l|}{ Gender } \\
\hline Female & 55 (14.9) & $203(55.2)$ & \multirow[t]{2}{*}{0.464} & $32(8.7)$ & $226(61.4)$ & \multirow[t]{2}{*}{0.011} \\
\hline Male & $28(7.6)$ & $82(22.3)$ & & $26(7.1)$ & $84(22.8)$ & \\
\hline \multicolumn{7}{|l|}{ Work experience } \\
\hline$\leq 5$ years & $19(5.2)$ & $75(20.4)$ & \multirow[t]{3}{*}{0.740} & $15(4.1)$ & 79 (21.5) & \multirow[t]{3}{*}{0.136} \\
\hline $6-10$ years & $27(7.3)$ & $82(22.3)$ & & $23(6.3)$ & $86(23.4)$ & \\
\hline$>10$ years & $37(10.1)$ & $128(34.8)$ & & $20(5.4)$ & $145(39.4)$ & \\
\hline \multicolumn{7}{|l|}{ Living area } \\
\hline Eastern Indonesia & $10(2.7)$ & $35(9.5)$ & \multirow[t]{3}{*}{0.969} & $7(1.9)$ & $38(10.3)$ & \multirow[t]{3}{*}{0.545} \\
\hline Central Indonesia & 40 (10.9) & $141(38.3)$ & & $25(6.8)$ & $156(42.4)$ & \\
\hline Western Indonesia & $33(9.0)$ & $109(29.6)$ & & $26(7.1)$ & $116(31.5)$ & \\
\hline \multicolumn{7}{|l|}{ Educational level } \\
\hline Diploma & $48(13.0)$ & $178(48.4)$ & \multirow[t]{3}{*}{0.349} & $37(10.1)$ & $189(51.4)$ & \multirow[t]{3}{*}{0.889} \\
\hline Bachelor's degree & $33(9.0)$ & $93(25.3)$ & & $19(5.2)$ & $107(29.1)$ & \\
\hline Master's degree & $2(0.5)$ & $14(3.8)$ & & $2(0.5)$ & $14(3.8)$ & \\
\hline \multicolumn{7}{|l|}{ Place of work } \\
\hline Rural & $47(12.8)$ & $155(42.1)$ & \multirow[t]{2}{*}{0.814} & $35(9.5)$ & $167(45.4)$ & \multirow[t]{2}{*}{0.444} \\
\hline Urban & $36(9.8)$ & $130(35.3)$ & & $23(6.3)$ & $143(38.9)$ & \\
\hline \multicolumn{7}{|l|}{ Source of information } \\
\hline Social media & $46(12.5)$ & $102(27.7)$ & \multirow{6}{*}{0.013} & $32(8.7)$ & $116(31.5)$ & \multirow{6}{*}{0.029} \\
\hline Television and radio & $7(1.9)$ & $30(8.2)$ & & $4(1.1)$ & $33(9.0)$ & \\
\hline Newspapers, magazines, posters, and pamphlets & $3(0.8)$ & $4(1.1)$ & & $3(0.8)$ & $4(1.1)$ & \\
\hline Nurses and other healthcare workers & $10(2.7)$ & $47(12.8)$ & & $5(1.4)$ & $52(14.1)$ & \\
\hline Seminars and workshops & $1(0.3)$ & $16(4.3)$ & & $1(0.3)$ & $16(4.3)$ & \\
\hline WHO and ministry of health websites & $16(4.3)$ & $86(23.4)$ & & $13(3.5)$ & $89(24.2)$ & \\
\hline
\end{tabular}


Table 3: Comparison of sociodemographic characteristics between public health nurses with mean scores of attitude $(\mathrm{n}=368)$

\begin{tabular}{|c|c|c|c|c|}
\hline \multirow[t]{2}{*}{ Variables } & \multicolumn{2}{|c|}{ Attitude } & \multirow[t]{2}{*}{$t / F$} & \multirow[t]{2}{*}{$p$-value } \\
\hline & Mean & SD & & \\
\hline \multicolumn{5}{|l|}{ Age } \\
\hline$\leq 30$ years & 33.28 & 2.95 & \multirow[t]{4}{*}{1.154} & \multirow[t]{4}{*}{0.327} \\
\hline $31-39$ years & 33.00 & 2.47 & & \\
\hline $40-49$ years & 32.97 & 2.81 & & \\
\hline$\geq 50$ years & 32.12 & 3.28 & & \\
\hline \multicolumn{5}{|l|}{ Gender } \\
\hline Female & 33.19 & 2.63 & \multirow[t]{2}{*}{-2.99} & \multirow[t]{2}{*}{0.003} \\
\hline Male & 32.79 & 2.87 & & \\
\hline \multicolumn{5}{|l|}{ Work experience } \\
\hline$\leq 5$ years & 33.69 & 2.53 & \multirow[t]{3}{*}{4.655} & \multirow[t]{3}{*}{0.010} \\
\hline $6-10$ years & 32.53 & 3.00 & & \\
\hline$>10$ years & 32.95 & 2.63 & & \\
\hline \multicolumn{5}{|l|}{ Living area } \\
\hline Eastern Indonesia & 32.48 & 3.64 & \multirow[t]{3}{*}{2.138} & \multirow[t]{3}{*}{0.119} \\
\hline Central Indonesia & 33.29 & 2.11 & & \\
\hline Western Indonesia & 32.82 & 3.10 & & \\
\hline \multicolumn{5}{|l|}{ Educational level } \\
\hline Diploma & 32.83 & 3.01 & \multirow[t]{3}{*}{1.338} & \multirow[t]{3}{*}{0.264} \\
\hline Bachelor's degree & 33.29 & 2.23 & & \\
\hline Master's degree & 33.43 & 2.47 & & \\
\hline \multicolumn{5}{|l|}{ Place of work } \\
\hline Rural & 33.19 & 2.63 & \multirow[t]{2}{*}{1.40} & \multirow[t]{2}{*}{0.163} \\
\hline Urban & 32.79 & 2.87 & & \\
\hline \multicolumn{5}{|l|}{ Source of information } \\
\hline Social media & 32.75 & 3.17 & \multirow[t]{6}{*}{2.428} & \multirow[t]{6}{*}{0.035} \\
\hline Television and radio & 33.94 & 1.74 & & \\
\hline Newspapers, magazines, posters, and pamphlets & 32.85 & 2.34 & & \\
\hline Nurses and other healthcare workers & 33.36 & 2.41 & & \\
\hline Seminars and workshops & 34.29 & 1.10 & & \\
\hline WHO and ministry of health websites & 32.65 & 2.66 & & \\
\hline
\end{tabular}

\section{Discussion}

To the best of our knowledge, there is no other study exploring the knowledge, attitude, and practices of PHNs and possible barriers perceived by PHNs to infection control practices in Indonesia. However, several studies have shown high levels of COVID-19 knowledge among the general population [16], [17]. This means that the transmission of disease will be very high if these barriers are not addressed.

Table 4: Correlation between knowledge, attitude, and practices among public health nurses $(n=368)$

\begin{tabular}{lll}
\hline Variable & Correlation coefficient & p-value \\
\hline Knowledge-attitude & $0.435^{*}$ & 0.000 \\
Attitude-practices & $0.314^{*}$ & 0.000 \\
Knowledge-practices & $0.362^{*}$ & 0.000 \\
\hline${ }^{*}$ Correlation significant at 0.01 level (2-tailed). &
\end{tabular}

The results of this study show that the majority of participants had good knowledge of COVID-19. This study is in line with previous studies in other countries that found that the majority of nurses and other HCWs had good knowledge about COVID-19. Saqlain et al. demonstrated that the majority of nurses $(90.5 \%)$ had good knowledge regarding COVID-19 in Pakistan [15]. Similarly, Giao et al.'s study showed that $88.4 \%$ of HCWs had sufficient knowledge regarding COVID19 [18] and Shi et al. showed that $89.51 \%$ of HCWs had a good knowledge of the COVID-19 epidemic. Their study results are slightly higher than the results of our study [19]. Olum et al. demonstrated that $69 \%$ of HCWs indicated good knowledge of COVID-19 at MaKCHS Teaching Hospitals in Uganda [20]. Nemati et al.'s study showed that $56.5 \%$ of nurses had good knowledge regarding COVID-19 infections in Iran [21]. Their study results are slightly lower than the results of this study.
This small difference could be explained by the cultural background of where the research was conducted.

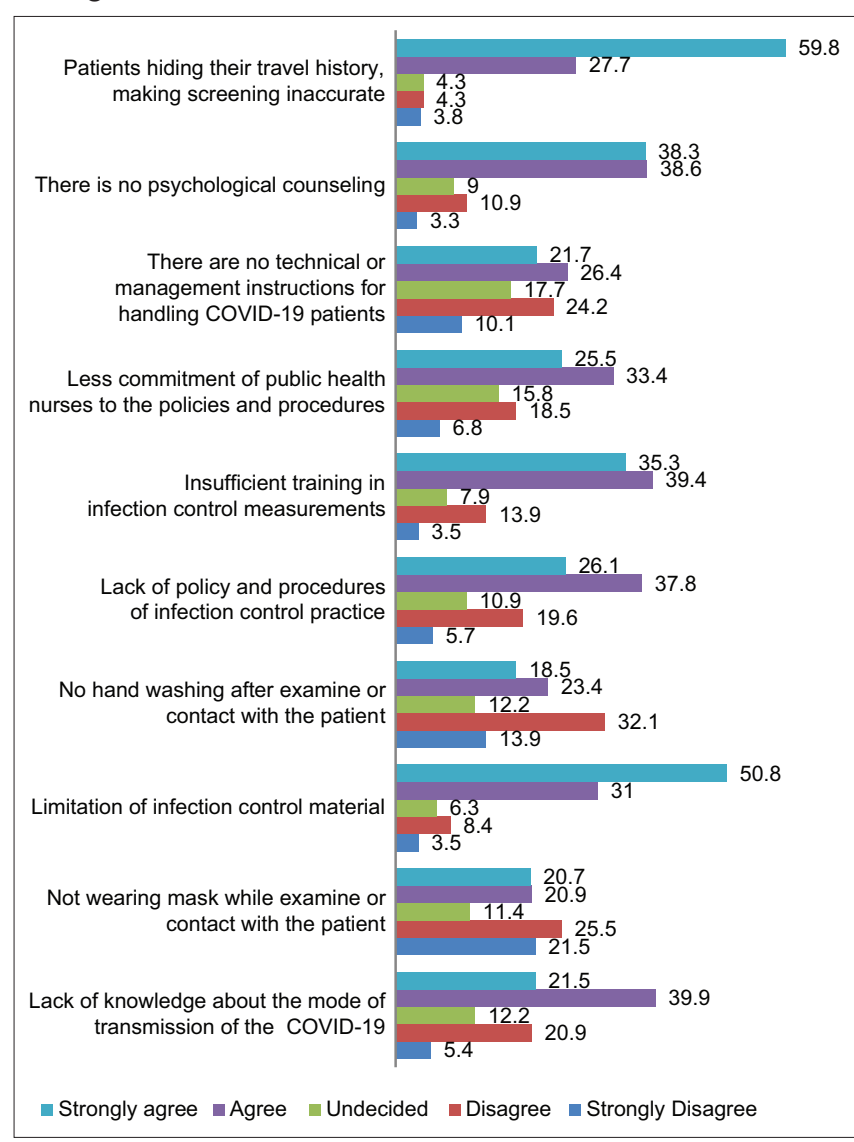

Figure 1: Perceived barriers to infection control practice among public health nurses in Indonesia $(n=368)$

The results of this study demonstrate that demographic characteristics such as age, gender, work experience, living area, educational level, and place of work were not significantly associated with knowledge. However, this study is slightly different from the studies conducted by Nemati et al. and Al-Hanawi et al. [21], [22]. Their studies demonstrated that knowledge was affected by age and educational level. The factor associated with knowledge in this study was the source of information. We report that social media was the first and main source for COVID-19 information for PHNs while the second source of COVID-19 information was the WHO and Ministry of Health websites. This result is in line with previous studies by Karasneh et al. [23] and Saqlain et al. [15] in which social media was the main source of HCWs' information about COVID-19. Media can improve the knowledge of HCWs by providing up-to-date information [23]. It can also bridge effective information and rapid global response for researchers, scientists, and public health experts [23], but some sources of information are unreliable, which has resulted in disinformation [24], [25]. Thus, PHNs must get information from the $\mathrm{WHO}$ and Ministry of Health of Indonesia's websites as reliable and trustworthy sources of information for COVID-19. This finding reinforces the result of a previous study that showed how good knowledge was supported by various news reports and media portals [26]. During the 
pandemic period in Indonesia, there have been many seminars and trainings held by the Indonesian National Nurses Association and Nursing Education Institution in Indonesia. These unyielding efforts by the nurse's association and education institution can be accessed easily to improve PHNs' knowledge.

The results of this study demonstrate that the majority of participants had a positive attitude toward COVID-19. This result is supported by Saqlain et al. [15] and Bhagavatula et al. [27], but differs with Olum et al., in which the majority of respondents had a poor attitude and only $21 \%$ had a good attitude. This study showed a positive correlation between knowledge and attitude. A similar result was also found by Zhang et al. [12]. Further analysis demonstrated that attitudes did not significantly different with age, living area, educational level, or place of work but were significantly different with gender, work experience, and source of information. Our study also reports that gender, work experience, and source of information affected PHNs' attitude regarding COVID19. The result of our study does not agree with Saqlain et al. [15] or Giao et al. [18], in which attitude did not differ significantly based on work experience or gender, but does agree in that attitude had no significant difference based on age.

The results of this study show that the majority of participants had good practices. This is in line with previous studies in other countries in which the majority of nurses and other HCWs had good practices to prevent and control COVID19. Saqlain et al. [15] demonstrated that $91.4 \%$ of nurses had good practices; Zhang et al. [12] showed that $89.7 \%$ of HCWs had good practices, and Olum et al. [20] showed $74 \%$ of HCWs had good practices regarding COVID-19. The findings of the present study demonstrate that age, work experience, living area, educational level, and place of work were not significantly associated with good practices. Factors associated with practices that we found were gender and source of information. Gender became one predictor of less optimistic attitudes toward COVID19 [28]. This study is in contrast with a previous study by Olum et al. [20], which demonstrated that age and educational levels were significantly associated with good practices. Saqlain et al. also demonstrated that work experience was significantly associated with good practices but that age and gender were not significantly associated with them. Interestingly, $77.4 \%$ of our study participants believed that every piece of relevant COVID-19 information should be relayed to their fellow nurses. This indicates that information plays a large role in shaping knowledge, attitudes, and general practices during the COVID-19 pandemic.

Our findings show that there were significant, positive linear correlations between knowledge and attitude, knowledge, and practices, attitude, and practices. These results complement conclusions from previous studies associating higher levels of knowledge with higher confidence and positive attitudes during the COVID-19 outbreak [16], [19]. Knowledge is essential for establishing prevention beliefs, fostering positive attitudes, and promoting good practices [12]. According to reasoned action theory, the motive of a behavior is related to an attitude [15]. These findings clearly indicate the importance of knowledge and how good sources of information are needed during the rapid rise of COVID-19 cases through health education. However, a specific design to deliver this health education should be tailored to address how male participants had worse health practices compared to female participants.

The results of our study demonstrate that the majority of PHNs perceived that limitations to infection control materials and patients hiding their travel history, making screening more inaccurate, were the major barriers. The government should provide more infection control materials to prevent and control infections in a primary health care setting. All residents should be honest in conveying their travel history to help break the chain of transmission and to help with early detection.

\section{Study limitation}

This online survey had a few limitations. The oversampling of specific sociodemographic characteristics such as gender $(70.1 \%)$ and a high proportion of diploma graduates $(61.4 \%)$ might have led to a selection bias. However, this study may serve as an important source of knowledge and awareness for $\mathrm{PHNs}$ living in Indonesia. Furthermore, this study was based on a self-reported questionnaire with a limited number of items that might not be representative of actual practice. Consequently, further study with focusgroup discussions and interviews might be needed to resolve this issue.

\section{Conclusions}

There was a significant association between the source of information and knowledge. There were significant differences of attitudes based on gender, work experience, and source of information. Factors associated with practices were gender and source of information. There were significant, positive linear correlations between knowledge, attitude, and practices. The majority of PHNs' perceived that limitations to infection control materials and patients hiding their travel history, making screening inaccurate, were the major barriers. 


\section{Acknowledgment}

The authors would like to thank all the PHNs in Indonesia involved in this study.

\section{References}

1. World Health Organization. Timeline of WHO's Response to COVID-19. Geneva: World Health Organization; 2020. Available from: https://www.who.int/news-room/detail/29-06-2020covidtimeline. [Last accessed on 2020 July 09].

2. World Health Organization. WHO Coronavirus Disease (COVID19) Dashboard. Geneva: World Health Organization; 2020. Available from: https://www.covid19.who.int. [Last accessed on 2020 August 07].

3. Indonesian Task Force for COVID-19. Data Distribution. Jakarta: Indonesian Task Force for COVID-19; 2020. Available from: https://www.covid19.go.id. [Last accessed on 2020 August 07].

4. Indonesia National Nursing Association. Affected nurse monitoring form. Jakarta: Indonesia National Nursing Association; 2020. Available from: https://www.covid19ppni.id/ form-pantauan-perawat. [Last accessed on 2020 Aug 07].

5. Edmonds JK, Kneipp SM, Campbell L. A call to action for public health nurses during the COVID-19 pandemic. Public Health Nurs. 2020;37(3):323-4. https://doi.org/10.1111/phn.12733 PMid:32281160

6. Yoshioka-Maeda K, Iwasaki-Motegi R, Honda C. Preventing the dysfunction of public health centres responding to COVID19 by focusing on public health nurses in Japan. J Adv Nurs. 2020;76(9):2215-6. https://doi.org/10.1111/jan.14409 PMid:32363578

7. Huang L, Lin G, Tang L, Yu L, Zhou Z. Special attention to nurses' protection during the COVID-19 epidemic. Crit Care. 2020;24(1):120. https://doi.org/10.1186/s13054-020-2841-7 PMid:32220243

8. Wong EL, Wong SY, Kung K, Cheung AW, Gao TT, Griffiths S. Will the community nurse continue to function during H1N1 influenza pandemic: A cross-sectional study of Hong Kong community nurses? BMC Health Serv Res. 2010;10:107. https:// doi.org/10.1186/1472-6963-10-107 PMid:20433691

9. Gan X, Shi Z, Chair SY, Cao X, Wang Q. Willingness of Chinese nurses to practice in Hubei combating the coronavirus disease 2019 epidemic: A cross-sectional study. J Adv Nurs. 2020;76:2137-50. https://doi.org/10.1111/jan.14434 PMid:32449187

10. Mhango M, Dzobo M, Chitungo I, Dzinamarira T. COVID-19 risk factors among health workers: A rapid review. Saf Health Work. 2020;11(3):262-5. https://doi.org/10.1016/j.shaw.2020.06.001 PMid:32995051

11. Bashirian S, Jenabi E, Khazaei S, Barati M, Karimi-Shahanjarini A, Zareian S, et al. Factors associated with preventive behaviours of COVID-19 among hospital staff in Iran in 2020: An application of the protection motivation theory. J Hosp Infect. 2020;105(3):4303. https://doi.org/10.1016/j.jhin.2020.04.035 PMid:32360337

12. Zhang $M$, Zhou M, Tang $F$, Wang $Y$, Nie H, Zhang $L$, et al. Knowledge, attitude, and practice regarding COVID-19 among healthcare workers in Henan, China. J Hosp Infect. 2020;105:183-7. https://doi.org/10.1016/j.jhin.2020.04.012

\section{PMid:32278701}

13. Gan WH, Lim JW, Koh D. Preventing intra-hospital infection and transmission of COVID-19in healthcare workers. Saf Health Work. 2020;11(2):241-3. https://doi.org/10.1016/j. shaw.2020.03.001

PMid:32292622

14. Creative Research System. Sample Size Calculator. California: Creative Research System; 2012. Available from: https://www. surveysystem.com/sscalc.htm. [Last accessed on 2020 May 10].

15. Saqlain M, Munir MM, Rehman SU, Gulzar A, Naz S, Ahmed Z, et al. Knowledge, attitude, practice and perceived barriers among healthcare professionals regarding COVID-19: A Crosssectional survey from Pakistan. J Hosp Infect. 2020;105(3):41923. https://doi.org/10.1016/j.jhin.2020.05.007 PMid:32437822

16. Zhong BL, Luo W, Li HM, Zhang QQ, Liu XG, Li WT, et al. Knowledge, attitudes, and practices towards COVID-19 among Chinese residents during the rapid rise period of the COVID-19 outbreak: A quick online cross-sectional survey. Int J Biol Sci. 2020;16(10):1745-52. https://doi.org/10.7150/ijbs.45221 PMid:32226294

17. Azlan AA, Hamzah MR, Sern TJ, Ayub SH, Mohamad E. Public knowledge, attitudes and practices towards COVID-19: A crosssectional study in Malaysia. PLoS One. 2020;15(5):e0233668. https://doi.org/10.1371/journal.pone.0233668 PMid:32437434

18. Giao H, Han NT, Khanh TV, Ngan TV, Tam VK. Knowledge and attitude toward COVID-19 among healthcare workers at district 2 hospital, Ho Chi Minh City. Asian Pac J Trop Med. 2020;13(6):260-5.

19. Shi Y, Wang J, Yang Y, Wang Z, Wang G, Hashimoto K, et al Knowledge and attitudes of medical staff in Chinese psychiatric hospitals regarding COVID-19. Brain Behav Immun Health. 2020;4:100064. https://doi.org/10.1016/j.bbih.2020.100064 PMid:32289123

20. Olum R, Chekwech G, Wekha G, Nassozi DR, Bongomin F. Coronavirus disease-2019: Knowledge, attitude, and practices of health care workers at Makerere University Teaching Hospitals, Uganda. Front Public Health. 2020;8:181. https://doi. org/10.3389/fpubh.2020.00181 PMid:32426320

21. Nemati M, Ebrahimi B, Nemati F. Assessment of Iranian nurses knowledge and anxiety toward COVID-19 during the current outbreak in Iran. Arch Clin Infect Dis. 2020;15:e102848. https:// doi.org/10.5812/archcid.102848

22. Al-Hanawi MK, Angawi K, Alshareef N, Qattan AM, Helmy HZ, Abudawood $\mathrm{Y}$, et al. Knowledge, attitude and practice toward COVID-19 among the public in the Kingdom of Saudi Arabia: A cross-sectional study. Front Public Health. 2020;8:217. https:// doi.org/10.3389/fpubh.2020.00217

23. Karasneh R, Al-Azzam S, Muflih S, Soudah O, Hawamdeh S, Khader Y. Media's effect on shaping knowledge, awareness risk perceptions and communication practices of pandemic COVID-19 among pharmacists. Res Social Adm Pharm. 2020;20:30430-7. https://doi.org/10.1016/j.sapharm.2020.04.027 PMid:32340892

24. The Jakarta Post. COVID-19: National Police to Take Legal Action against 41 People Over Internet Hoaxes. Jakarta: The Jakarta Post; 2020. Available from: https://www.thejakartapost. $\mathrm{com} /$ news/2020/03/24/covid-19-national-police-to-take-legalaction-against-41-people-over-internet-hoaxes.html. [Last accessed on 2020 Aug 01]. https://doi.org/10.1136/bmj.m3333

25. Wijaya MC. We can all Help Fight Fake News and Hysteria over COVID-19. Jakarta: The Jakarta Post; 2020. Available from: https://www.thejakartapost.com/academia/2020/03/06/we-canall-help-fight-fake-news-and-hysteria-over-covid-19.html. [Last 
accessed on 2020 Aug 01]. https://doi.org/10.31234/osf.io/ qfnm3

26. Mansuri FM, Zalat MM, Khan AA, Alsaedi EQ, Ibrahim HM. Estimating the public response to mitigation measures and self-perceived behaviours towards the COVID-19 pandemic. J Taibah Univ Med Sci. 2020;15(4):278-83. https://doi. org/10.1016/j.jumed.2020.06.003

PMid:32837504

27. Bhagavathula AS, Aldhaleei WA, Rahmani J, Mahabadi MA, Bandari DK. Knowledge and perceptions of COVID-19 among health care workers: Cross-sectional study. JMIR Public Health Surveill. 2020;6(12):e19160. https://doi.org/10.2196/ preprints.19160

PMid:32320381

28. Yahya AN. Ministry of Communication and Information: 1,125 Hoax Content and Disinformation Spread during the Covid19 Pandemic. Jakarta: Kompas; 2020. Available from: https:// www.nasional.kompas.com/read/2020/04/08/13312131/ menkominfo-1125-konten-hoaks-dan-disinformasi-tersebarselama-pandemi-covid. [Last accessed on 2020 Aug 01]. 